\title{
ANTIFUNGAL, ANTIBACTERIAL AND CYTOTOXIC ACTIVITIES OF NON-INDIGENOUS MEDICINAL PLANTS NATURALISED IN MALAYSIA
}

\author{
CHEONG WEI ONG ${ }^{1}$, YIK SIN CHAN ${ }^{1}$, SZE MUN CHAN ${ }^{1}$, MAAN WAI CHAN ${ }^{1}$, ENG LOON \\ $\mathrm{TEH}^{1}$, CAI LING DEMI SOH ${ }^{1}$, KONG SOO $\mathrm{KHOO}^{2}$, HEAN CHOOI ONG ${ }^{3}$, NAM WENG SIT ${ }^{1} *$ \\ ${ }^{I}$ Department of Allied Health Sciences, Faculty of Science, Universiti Tunku Abdul Rahman, Bandar Barat, 31900 Kampar, \\ Perak, Malaysia \\ ${ }^{2}$ Department of Chemical Science, Faculty of Science, Universiti Tunku Abdul Rahman, Bandar Barat, 31900 Kampar, \\ Perak, Malaysia \\ ${ }^{3}$ Institute of Biological Sciences, Faculty of Science, University of Malaya, 50603 Kuala Lumpur, Malaysia
}

*corresponding author: sitnw@utar.edu.my

Manuscript received: March 2018

\begin{abstract}
The evolution of antibiotic resistance in microbes has been an obstacle to antimicrobial therapy. This necessitates the search for new pharmaceuticals from natural resources or synthetic approaches. This study was conducted to evaluate the antifungal, antibacterial and cytotoxic activities of six non-indigenous medicinal plants naturalised in Malaysia. Thirty six extracts from the leaves of Ailanthus triphysa (Dennst.) Alston (Simaroubaceae), Clinacanthus nutans (Burm. f.) Lindau (Acanthaceae), Gynostemma pentaphyllum (Thunb.) Makino (Cucurbitaceae), Gynura bicolor (Roxb. ex Willd.) DC. (Compositae), Turnera subulata Sm. (Passifloraceae), and the aerial part of Asystasia gangetica (L.) T. Anderson (Acanthaceae) were assessed for antimicrobial activities using a colorimetric broth microdilution method. The toxicity of plants extracts was examined using African monkey kidney epithelial (Vero) cells. The plant extracts showed rather a strong antifungal activity than an antibacterial activity. The four yeasts were more susceptible to the plant extracts than the two filamentous fungi. The ethanol extract of Ailanthus triphysa (Dennst.) Alston resulted in the lowest minimum inhibitory concentration (MIC), 0.0025 $\mathrm{mg} / \mathrm{mL}$, while the ethyl acetate, ethanol, methanol and water extracts gave the lowest minimum fungicidal concentration $(0.02 \mathrm{mg} / \mathrm{mL})$ against Candida krusei. For antibacterial activity, the lowest MIC value $(0.08 \mathrm{mg} / \mathrm{mL})$ was shown by the ethyl acetate extract of Gynostemma pentaphyllum (Thunb.) Makino against both Gram-positive bacteria Bacillus cereus and Staphylococcus aureus. For cytotoxic activity, unlike other plants, all the extracts of Ailanthus triphysa (Dennst.) Alston and Gynura bicolor (Roxb. ex Willd.) DC. possessed significant toxicity ( $<<0.05)$ towards the Vero cells. The results indicate that the hexane and chloroform extracts of Asystasia gangetica (L.) T. Anderson are non-toxic to mammalian cells, potent and have broad spectrum activity against human fungal pathogens, and thus are potential sources of new antifungal compounds.
\end{abstract}

\section{Rezumat}

Evoluția rezistenței germenilor patogeni la antibiotice reprezintă un obstacol pentru terapia antimicrobiană, implicând cercetări privind descoperirea de noi substanțe active, din sursă naturală sau de sinteză. Acest studiu evaluează activitatea antifungică, antibacteriană și citotoxică a treizeci și șase de extracte provenind de la Ailanthus triphysa (Dennst.) Alston (Simaroubaceae), Clinacanthus nutans (Burm. f.) Lindau (Acanthaceae), Gynostemma pentaphyllum (Thunb.) Makino (Cucurbitaceae), Gynura bicolor (Roxb. ex Willd.) DC. (Compositae), Turnera subulata Sm. (Passifloraceae), Asystasia gangetica (L.) T. Anderson (Acanthaceae). Acestea au demonstrat activitate antifungică superioară celei antibacteriene. Extractul etanolic de Ailanthus triphysa (Dennst.) Alston a prezentat ce mai mică concentrație inhibitorie (CIM), 0,0025 $\mathrm{mg} / \mathrm{mL}$, în timp ce extractele obținute în acetat de etil, metanol, etanol și apă au generat cea mai mică concentrație inhibitorie fungicidă, $0,02 \mathrm{mg} / \mathrm{mL}$, împotriva Candida krusei. Referitor la activitatea antibacteriană, cea mai mică valoare a CIM $(0,08$ $\mathrm{mg} / \mathrm{mL}$ ) a fost obținută de extractul cu acetat de etil din Gynostemma pentaphyllum (Thunb.) Makino împotriva bacteriilor Gram-pozitive Bacillus cereus și Staphylococcus aureus. În ceea ce privește activitatea citotoxică, spre deosebire de alte plante, toate extractele de Ailanthus triphysa (Dennst.) Alston și Gynura bicolor (Roxb. Ex Willd.) DC. posedă toxicitate semnificativă $(\mathrm{p}<0,05)$ asupra unei linii celulare renale. Rezultatele indică faptul că extractele în hexan și cloroform din Asystasia gangetica (L.) T. Anderson sunt non-toxice pentru celulele studiate și au activitate cu spectru larg împotriva agenților patogeni fungici umani și, prin urmare, pot fi considerate surse potențiale de noi compuși antifungici.

Keywords: bacteriostatic, bactericidal, fungistatic, fungicidal, Vero cell 


\section{Introduction}

Despite advances in the development of antimicrobials and vaccines, infectious diseases remain a major leading cause of death worldwide. According to the World Health Organizations (WHO) estimates, lower respiratory tract infections and diarrhoeal diseases are among the top 10 killers, accounted for 3.1 million and 1.5 million of deaths respectively in 2012. Moreover, infectious diseases were also responsible for approximately $50 \%$ of all deaths among children under five years of age in 2013 [41]. Bacteria are a major etiological agent for lower respiratory tract infections and diarrhoeal diseases. Various classes of antibiotics have been developed and introduced into clinical use [18]. However, the indiscriminate use of these antibiotics by humans over many years has resulted in the emergence of resistant bacterial strains. The antibiotic resistance is associated with increased risk of complications and mortality, loss of productivity, and has also negatively impacted the medical costs and resource utilisation at healthcare facilities [7, 35].

Approximately 20 - $25 \%$ of the world population suffers from superficial fungal infections such as dermatophytosis which is caused by a group of keratinophilic fungi from the genera of Trichophyton, Microsporum and Epidermophyton [17, 27]. There has also been a rise of invasive fungal infections such as candidiasis, aspergillosis and cryptococcosis over the past two decades in patients with human immunodeficiency virus/acquired immunodeficiency syndrome (HIV/AIDS), cancer chemotherapy, haematopoietic cell and solid organ transplantation, immunosuppression treatment and critically ill patients in intensive care unit [21]. The development of antifungal agents is lagging behind that of antibiotics. As human and fungi are both eukaryotes, the discovery of compounds that are selective to fungi and at the same time do not cause toxicities or side effects to human is a challenge. The emergence of drug-resistant strains, the rising concern of about side effects or adverse effects, undesirable drug interactions, long duration and high cost of antifungal treatment $[2,13,36]$ have necessitated a search for alternative treatments, for example from synthetic approaches or natural resources such as medicinal plants. Medicinal plants have been used to treat various ailments in traditional medicine systems for thousands of years. Even with the advent of modern medicine, using plants for medicinal purposes is still prevalent in many parts of the world [34]. WHO estimates that $80 \%$ of the world population uses herbal medicines for some aspects of primary health care [42]. The increasing interest in medicinal plants reflects recognition of the validity of many traditional claims regarding the value of natural products in health care. Since plants produce a diverse variety of secondary metabolites such as alkaloids, anthraquinones, flavonoids, lignans, tannins, etc. as part of their defence mechanisms against microbial infections [11], medicinal plants are promising sources of new antimicrobial compounds. With its tropical temperature and high rainfall, Malaysia is bestowed with rich botanical wealth. This study aims to evaluate six non-indigenous medicinal plants that have been naturalised in Malaysia for antifungal and antibacterial activities. The plants tested were Ailanthus triphysa (Dennst.) Alston (Simaroubaceae; White siris), Turnera subulata Sm. (Passifloraceae; White buttercup), Asystasia gangetica (L.) T. Anderson (Acanthaceae; "Chinese Violet"), Clinacanthus nutans (Burm. f.) Lindau (Acanthaceae; "Sabah Snake Grass"), Gynostemma pentaphyllum (Thunb.) Makino (Cucurbitaceae; "Jiaogulan"), and Gynura bicolor (Roxb. ex Willd.) DC. (Compositae; Okinawan spinach). The first two plants are relatively less studied scientifically while the latter plants have been reported to possess various biological activities, including anti-inflammatory, antioxidative, hypoglycaemic, hypolipidaemic and anticancer activities [3, 31, 37-39, 43]. However, very little information is available regarding their activity against human pathogens. In addition, the toxicity of each plant extract was also examined using a mammalian cell line.

\section{Materials and Methods}

\section{Plant materials}

The leaves of Ailanthus triphysa (Dennst.) Alston and Gynura bicolor (Roxb. ex Willd.) DC. were harvested from an organic farm in Bentong, Pahang state, Malaysia. The aerial part (excluding flowers) of Asystasia gangetica (L.) T. Anderson, and the leaves of Clinacanthus nutans (Burm. f.) Lindau, Gynostemma pentaphyllum (Thunb.) Makino and Turnera subulata $\mathrm{Sm}$. were obtained from different towns in the state of Perak in Malaysia. The plant materials were collected in fresh and before blooming except Asystasia gangetica (L.) T. Anderson and Turnera subulata $\mathrm{Sm}$. which were during blooming season. Upon collection, the materials were transported to the laboratory for processing. The species identification was performed by Professor Hean Chooi Ong, an ethnobotanist at the Institute of Biological Sciences, Faculty of Science, University of Malaya, Malaysia. Specimen vouchers of the plants were prepared and deposited at the Faculty of Science, Universiti Tunku Abdul Rahman, Perak, Malaysia. The voucher was labelled as UTAR/FSC/11/004 for Ailanthus triphysa (Dennst.) Alston, UTAR/FSC/12/001 for Asystasia gangetica (L.) T. Anderson, UTAR/FSC/11/003 for Clinacanthus nutans (Burm. f.) Lindau, UTAR/FSC/ 12/010 for Gynostemma pentaphyllum (Thunb.) Makino, UTAR/FSC/11/005 for Gynura bicolor (Roxb. ex Willd.) DC. and UTAR/FSC/12/002 for Turnera subulata $\mathrm{Sm}$. Preparation of plant extracts

The plant materials were cleaned, cut and blended. The blended plant materials were then sequentially 
FARMACIA, 2020, Vol. 68, 4

extracted using hexane, chloroform, ethyl acetate, ethanol, methanol and sterile distilled water at room temperature and with agitation (120 rpm). Three cycles (one day/cycle) of maceration were performed for each solvent. The filtrate for each organic solvent was evaporated in vacuo while the water extract was lyophilised. All the dried extracts were kept at $-20^{\circ} \mathrm{C}$ prior to bioassay.

Antifungal assay

Four species of yeasts (Candida albicans $\mathrm{ATCC}^{\circledR}$ $90028^{\mathrm{TM}}$, Candida parapsilosis ATCC ${ }^{\circledR} 22019^{\mathrm{TM}}$, Candida krusei $\mathrm{ATCC}^{\circledR} 6258^{\mathrm{TM}}$ (teleomorph) and Cryptococcus neoformans $\mathrm{ATCC}^{\circledR} 90112^{\mathrm{TM}}$ ) and two species of filamentous fungi (Aspergillus fumigatus ATCC ${ }^{\circledR} 204305^{\mathrm{TM}}$ and Trichophyton interdigitale $\mathrm{ATCC}^{\circledR} 9533^{\mathrm{TM}}$ ) were purchased from American Type Culture Collection for the study. All the yeasts were sub-cultured on Sabouraud dextrose agar (SDA) whereas the filamentous fungi were sub-cultured on potato dextrose agar (PDA). The fungal inocula were prepared for antifungal assay according to the guidelines published by Clinical Laboratory Standards Institute [9, 10].

A colorimetric broth microdilution method as described by Eloff [14] was used, albeit with some modifications. The stock solution of each plant extract was prepared at $10 \mathrm{mg} / \mathrm{mL}$ in a methanol-water mixture $(2: 1, \mathrm{v} / \mathrm{v})$. The stock solution was two-fold serially diluted with RPMI-1640 medium in 96-well microplates to achieve final concentrations ranging from 0.02 to $2.50 \mathrm{mg} / \mathrm{mL}$. Amphotericin B (an antifungal drug) with a final concentration range of 0.06 to $8 \mu \mathrm{g} / \mathrm{mL}$ was used as a positive control. Fifty $\mu \mathrm{L}$ of the prepared fungal inoculum was added into the wells, making the total volume of each well $100 \mu \mathrm{L}$. Sterility control (medium only), growth control (fungus only) and negative control (extract only) were included in each microplate. The microplates were incubated at $35^{\circ} \mathrm{C}$ and $48 \mathrm{~h}$ for Candida spp; $35^{\circ} \mathrm{C}$ and $72 \mathrm{~h}$ for Cryptococcus neoformans and Aspergillus fumigatus, and $28^{\circ} \mathrm{C}$ and 7 days for Trichophyton interdigitale. After incubation, $20 \mu \mathrm{L}$ of $p$-iodonitrotetrazolium chloride (INT; $0.4 \mathrm{mg} / \mathrm{mL}$ ), which acts as a growth indicator, was added to each well. The colour change of the indicator was then observed and the minimum inhibitory concentration (MIC) was recorded. Twenty $\mu \mathrm{L}$ of the content of the well which had inhibitory activity (the indicator remained colourless) was inoculated onto SDA/PDA and incubated accordingly. Formation of fungal colony on the agar surface was observed and the minimum fungicidal concentration (MFC) was determined. Each extract was tested in triplicate.

Antibacterial assay

Two species of Gram-positive bacteria (Bacillus cereus $\mathrm{ATCC}^{\circledR} 11778^{\mathrm{TM}}$ and Staphylococcus aureus $\mathrm{ATCC}^{\circledR}$ $\left.6538^{\mathrm{TM}}\right)$ and four species of Gram-negative bacteria (Acinetobacter baumannii ATCC ${ }^{\circledR} 19606^{\mathrm{TM}}$, Escherichia coli $\mathrm{ATCC}^{\circledR} 35218^{\mathrm{TM}}$, Klebsiella pneumoniae $\mathrm{ATCC}^{\circledR}$ $13883^{\mathrm{TM}}$ and Pseudomonas aeruginosa $\mathrm{ATCC}^{\circledR} 27853^{\mathrm{TM}}$ ) obtained from American Type Culture Collection were evaluated in the study. The bacteria were subcultured on Mueller-Hinton agar (MHA). The bacterial inocula were prepared according to the Clinical Laboratory Standards Institute guidelines [9].

A colorimetric broth microdilution method as described by Eloff [14] was adopted with modifications. The stock solution of each plant extract $(10 \mathrm{mg} / \mathrm{mL})$ was prepared in a methanol-water mixture $(2: 1, \mathrm{v} / \mathrm{v})$. The stock solution was two-fold serially diluted with MuellerHinton broth (MHB) in 96-well microplates to achieve final concentrations ranging from 0.02 to $2.50 \mathrm{mg} / \mathrm{mL}$. Chloramphenicol (an antibacterial agent) with a final concentration range of 1 to $128 \mu \mathrm{g} / \mathrm{mL}$ was used as a positive control. Fifty $\mu \mathrm{L}$ of the prepared bacterial inoculum was added to the wells, making the total volume of each well $100 \mu \mathrm{L}$. Sterility control (medium only), growth control (bacterium only) and negative control (extract only) were included in each microplate. The microplates were incubated at $37^{\circ} \mathrm{C}$ for $24 \mathrm{~h}$. After incubation, $20 \mu \mathrm{L}$ of INT $(0.4 \mathrm{mg} / \mathrm{mL})$ was added into each well. The colour change of the indicator was observed and the minimum inhibitory concentration (MIC) was recorded. The content $(20 \mu \mathrm{L})$ from the wells which showed inhibitory activity (the indicator remained colourless) was inoculated onto MHA and incubated at $37^{\circ} \mathrm{C}$ for $24 \mathrm{~h}$. Formation of bacterial colony on the agar surface was observed and the minimum bactericidal concentration (MBC) was determined. The assay was conducted in triplicate.

Cytotoxicity assay

African monkey kidney epithelial (Vero) cell line (ATCC ${ }^{\circledR} \mathrm{CCL}-81^{\mathrm{TM}}$ ), a normal mammalian cell line, was used for the cytotoxicity assay. The cells were grown in culture flasks containing Dulbecco's modified Eagle's medium (DMEM) supplemented with 5\% foetal bovine serum (FBS), $1 \%$ penicillin-streptomycin solution and $3.7 \mathrm{~g} / \mathrm{L}$ of sodium bicarbonate, at $37^{\circ} \mathrm{C}$ in a $5 \% \mathrm{CO}_{2}$ atmosphere for $24 \mathrm{~h}$. The cells were then harvested from the culture flasks and cell count was performed using a haemocytometer. A cell concentration of $4 \times 10^{4}$ cells/well was seeded into each well and incubated at $37^{\circ} \mathrm{C}$ in a $5 \% \mathrm{CO}_{2}$ atmosphere for $24 \mathrm{~h}$. The plant extract was dissolved in a dimethyl sulfoxide-ethanol mixture $(60: 40, \mathrm{v} / \mathrm{v})$ to achieve a stock concentration of $512 \mathrm{mg} / \mathrm{mL}$, and subsequently diluted two-fold serially in maintenance medium (DMEM with $1 \%$ FBS) to obtain eight final concentrations (5 $640 \mu \mathrm{g} / \mathrm{mL}$ ) for cytotoxicity assay. One hundred $\mu \mathrm{L}$ of diluted stocks was introduced into the respective wells in 96-well microplates containing confluent monolayer of Vero cells and incubated at $37^{\circ} \mathrm{C}$ and $5 \% \mathrm{CO}_{2}$ atmosphere for $72 \mathrm{~h}$. Medium control, positive control (cells only) and negative control (dimethyl sulfoxide-ethanol mixture) were incorporated in each microplate. The viability of the cells after incubation was assessed by the neutral red uptake assay [30]. The assay was carried out in triplicate. 
FARMACIA, 2020, Vol. 68, 4

Data analysis

The MIC, MBC and MFC values were reported as the mean of three consistent replicates. The percentage of cell viability was expressed as mean \pm standard deviation of three replicates. The median cytotoxic concentration $\left(\mathrm{CC}_{50}\right)$ was determined from the plot of percentage cell viability against concentration of extract. The percentages of cell viability at different concentrations were analysed by one-way analysis of variance using the IBM $^{\circledR}$ SPSS $^{\circledR}$ Statistics (Version 20) software. The significance level was set at $\mathrm{p}<0.05$. Post hoc test, either with Tukey's (equal variance assumed) or Dunnett's (equal variance not assumed) test was further conducted to determine which concentration of an extract that produced significant result.

\section{Results and Discussion}

\section{Antifungal assay}

The antimicrobial activity of a plant extract can be detected qualitatively or quantitatively. A colorimetric broth microdilution method was deployed to quantitate and distinguish the antimicrobial activity into fungistatic/bacteriostatic and fungicidal/bactericidal, which are expressed as minimum inhibitory concentration

(MIC) and minimum fungicidal/bactericidal concentration (MFC/MBC), respectively. A polyene antifungal drug, amphotericin B was used as the positive control for the assay, and all the fungal species were susceptible to it with a MIC range of 0.125 to $8 \mu \mathrm{g} / \mathrm{mL}$. As evident in Table I, not every plant extract possesses fungistatic and fungicidal activities at the same time. Considering one extract against one fungus as a single bioassay, $81.0 \%(175 / 216)$ of the bioassays showed fungistatic activity whereas only $50.9 \%$ (110/ 216) of the bioassays exhibited fungicidal activity. The strongest fungistatic activity denoted by the lowest MIC value was given by the ethanol extract of Ailanthus triphysa (Dennst.) Alston against Candida krusei, which is $0.0025 \mathrm{mg} / \mathrm{mL}$ after further dilutions were performed beyond the initial testing concentration range. This value was comparable to the MIC values of amphotericin B $(1-2 \mu \mathrm{g} / \mathrm{mL})$ against Candida krusei. In contrast, the lowest MFC value was recorded at $0.02 \mathrm{mg} / \mathrm{mL}$, a concentration which is almost 10 times higher than the lowest MIC value. This MFC value was documented in the ethyl acetate, ethanol, methanol and water extracts of Ailanthus triphysa (Dennst.) Alston against Candida krusei.

Table I

Minimum inhibitory concentration (MIC) and minimum fungicidal concentration (MFC) of extracts from six medicinal plants against yeasts and filamentous fungi

\begin{tabular}{|c|c|c|c|c|c|c|c|c|c|c|c|c|}
\hline & \multicolumn{8}{|c|}{ Yeast } & \multicolumn{4}{|c|}{ Filamentous fungi } \\
\hline \multirow[t]{2}{*}{ Extract } & \multicolumn{2}{|c|}{ Candida albicans } & \multicolumn{2}{|c|}{$\begin{array}{c}\text { Candida } \\
\text { parapsilosis }\end{array}$} & \multicolumn{2}{|c|}{ Candida krusei } & \multicolumn{2}{|c|}{$\begin{array}{l}\text { Cryptococcus } \\
\text { neoformans }\end{array}$} & \multicolumn{2}{|c|}{$\begin{array}{l}\text { Aspergillus } \\
\text { fumigatus }\end{array}$} & \multicolumn{2}{|c|}{$\begin{array}{c}\text { Trichophyton } \\
\text { interdigitale }\end{array}$} \\
\hline & MIC $^{\mathbf{a}}$ & MFC $^{\mathbf{a}}$ & MIC & MFC & MIC & MFC & MIC & MFC & MIC & MFC & MIC & MFC \\
\hline
\end{tabular}

Ailanthus triphysa (Dennst.) Alston

\begin{tabular}{c|c|c|c|c|c|c|c|c|c|c|c|c|}
\multicolumn{2}{l}{ Ailanthus triphys (Dennst.) Alston } \\
HE & 0.31 & 0.63 & 0.31 & 0.63 & 0.08 & 0.16 & 0.08 & 0.16 & NA & - & 1.25 & 2.50 \\
CH & 0.31 & 1.25 & 0.16 & 2.50 & 0.16 & 0.31 & 0.16 & 2.50 & NA & - & 1.25 & 2.50 \\
EA & 0.02 & 0.63 & 0.01 & 1.25 & 0.02 & 0.02 & 0.16 & 1.25 & 1.25 & NA & 0.08 & 0.31 \\
ET & 0.005 & NA & 0.01 & NA & 0.0025 & 0.02 & 1.25 & 2.50 & 0.63 & NA & 0.16 & 1.25 \\
MT & 0.01 & NA & 0.02 & NA & 0.005 & 0.02 & 0.08 & 2.50 & 0.63 & NA & 0.16 & 0.63 \\
WA & 0.08 & NA & 0.02 & NA & 0.005 & 0.02 & 0.16 & NA & 0.63 & NA & 0.31 & NA \\
\hline
\end{tabular}

Asystasia gangetica (L.) T. Anderson

\begin{tabular}{|l|l|l|l|l|l|l|l|l|l|l|l|l|}
$\mathrm{HE}$ & 0.31 & 1.25 & 0.31 & 0.31 & 0.08 & 0.08 & 0.02 & 0.08 & 0.63 & NA & 0.31 & NA \\
$\mathrm{CH}$ & 0.31 & 2.50 & 0.31 & 0.63 & 0.16 & 0.31 & 0.08 & 0.16 & 0.63 & NA & 0.63 & 1.25 \\
$\mathrm{EA}$ & 0.16 & 1.25 & 0.16 & 0.63 & 0.16 & 1.25 & 0.08 & 0.31 & 0.63 & NA & 0.63 & 0.63 \\
$\mathrm{ET}$ & 0.63 & NA & 0.63 & 1.25 & 0.08 & NA & 0.08 & 0.16 & NA & - & 0.63 & NA \\
MT & 0.31 & 2.50 & 0.63 & 1.25 & 0.16 & 2.50 & 0.08 & 0.31 & NA & - & 0.63 & 0.63 \\
WA & 1.25 & NA & 1.25 & NA & 0.31 & NA & 0.31 & NA & NA & - & 2.50 & NA \\
\hline
\end{tabular}

Clinacanthus nutans (Burm. f.) Lindau

\begin{tabular}{l|l|l|l|l|l|l|l|l|l|l|l|l|} 
HE & 0.63 & 0.63 & 0.31 & 0.63 & 0.31 & 0.31 & 0.08 & 0.31 & 2.50 & NA & 0.63 & NA \\
CH & 0.63 & NA & 0.63 & 1.25 & 0.31 & 0.31 & 0.16 & 0.31 & NA & - & NA & - \\
EA & 0.63 & 0.63 & 0.31 & 0.63 & 0.16 & 0.31 & 0.16 & 0.63 & NA & - & 0.63 & 1.25 \\
ET & 0.63 & NA & 0.31 & 1.25 & 0.16 & 0.31 & 0.16 & NA & NA & - & NA & - \\
MT & 0.63 & NA & 0.31 & 2.50 & 0.16 & 0.31 & 0.16 & NA & NA & - & NA & - \\
WA & 0.31 & NA & 0.16 & NA & 0.16 & 0.31 & 0.08 & 1.25 & NA & - & NA & - \\
\hline
\end{tabular}

Gynostemma pentaphyllum (Thunb.) Makino

\begin{tabular}{l|c|c|c|c|c|c|c|c|c|c|c|c|} 
HE & 0.31 & 0.63 & 0.63 & 1.25 & 0.16 & 0.31 & 0.08 & 0.16 & NA & - & 0.31 & NA \\
CH & 0.31 & 1.25 & 1.25 & NA & 0.31 & 0.31 & 0.31 & 0.31 & NA & - & 0.63 & NA \\
EA & 0.16 & 0.63 & 0.63 & NA & 0.16 & 0.31 & 0.16 & 0.16 & NA & - & 0.16 & NA \\
ET & 1.25 & NA & NA & - & 0.63 & 2.50 & 0.16 & 1.25 & NA & - & 1.25 & NA \\
MT & NA & - & NA & - & 0.63 & NA & 0.08 & NA & NA & - & NA & - \\
WA & 1.25 & NA & 1.25 & NA & 0.63 & NA & 0.16 & NA & NA & - & NA & - \\
\hline
\end{tabular}


FARMACIA, 2020, Vol. 68, 4

\begin{tabular}{|c|c|c|c|c|c|c|c|c|c|c|c|c|}
\hline & \multicolumn{8}{|c|}{ Yeast } & \multicolumn{4}{|c|}{ Filamentous fungi } \\
\hline \multirow[t]{2}{*}{ Extract } & \multicolumn{2}{|c|}{ Candida albicans } & \multicolumn{2}{|c|}{$\begin{array}{c}\text { Candida } \\
\text { parapsilosis }\end{array}$} & \multicolumn{2}{|c|}{ Candida krusei } & \multicolumn{2}{|c|}{$\begin{array}{l}\text { Cryptococcus } \\
\text { neoformans }\end{array}$} & \multicolumn{2}{|c|}{$\begin{array}{l}\text { Aspergillus } \\
\text { fumigatus }\end{array}$} & \multicolumn{2}{|c|}{$\begin{array}{c}\text { Trichophyton } \\
\text { interdigitale }\end{array}$} \\
\hline & MIC $^{a}$ & MFC $^{\mathbf{a}}$ & MIC & MFC & MIC & MFC & MIC & MFC & MIC & MFC & MIC & MFC \\
\hline \multicolumn{13}{|c|}{ Gynura bicolor (Roxb. ex Willd.) DC. } \\
\hline $\mathrm{HE}$ & 0.31 & 1.25 & 0.16 & 0.16 & 0.04 & 0.08 & 0.04 & 0.31 & NA & - & 0.31 & NA \\
\hline $\mathrm{CH}$ & 0.31 & 0.63 & 0.16 & 0.31 & 0.04 & 0.08 & 0.08 & 0.16 & NA & - & 0.31 & NA \\
\hline EA & 0.31 & 0.63 & 0.31 & 0.63 & 0.16 & 0.16 & 0.08 & 1.25 & NA & - & 0.63 & NA \\
\hline ET & 0.31 & 2.50 & 0.31 & 0.63 & 0.16 & 0.16 & 0.08 & NA & NA & - & 0.63 & NA \\
\hline MT & 0.31 & 0.63 & 0.63 & 0.63 & 0.16 & 0.31 & 0.08 & 0.31 & NA & - & 0.63 & NA \\
\hline WA & 0.63 & 1.25 & 0.63 & 1.25 & 0.31 & 0.63 & 0.08 & 1.25 & NA & - & 2.50 & NA \\
\hline \multicolumn{13}{|c|}{ Turnera subulata $\mathrm{Sm}$. } \\
\hline HE & 0.31 & 2.50 & 0.16 & 0.63 & 0.04 & 0.16 & 0.02 & 0.16 & NA & - & 0.31 & NA \\
\hline $\mathrm{CH}$ & 0.63 & NA & 0.63 & 0.63 & 0.31 & 0.63 & 0.04 & 0.16 & NA & - & 0.63 & NA \\
\hline EA & 0.31 & 2.50 & 0.31 & 1.25 & 0.16 & 0.31 & 0.08 & 0.31 & NA & - & NA & - \\
\hline ET & 1.25 & NA & 1.25 & NA & 0.63 & 2.50 & 0.16 & NA & NA & - & NA & - \\
\hline MT & 1.25 & NA & 1.25 & NA & 0.63 & 2.50 & 0.16 & NA & NA & - & NA & - \\
\hline WA & 1.25 & NA & 2.50 & NA & 0.63 & 2.50 & 0.16 & NA & NA & - & NA & - \\
\hline Antibiotic $^{\mathrm{b}}$ & $0.5-1.0$ & & 1.0 & & $1.0-2.0$ & & 0.125 & & 8 & & $2-4$ & \\
\hline
\end{tabular}

a The MIC and MFC values are expressed as the mean of three consistent replicates in $\mathrm{mg} / \mathrm{mL}$. ${ }^{\mathrm{b}}$ Amphotericin B was used as the positive control and the values are expressed in $\mu \mathrm{g} / \mathrm{mL}$. HE, hexane extract; $\mathrm{CH}$, chloroform extract; EA, ethyl acetate extract; ET, eth anol extract; MT, methanol extract; WA, water extract; NA denotes no activity while "_" denotes not tested due to absence of inhibitory activity.

Among the fungi evaluated in this study, Table I clearly indicates that yeasts were more susceptible to the activity of plant extracts than filamentous fungi. The sensitivity of a fungus to plant extracts can be expressed in the form of fungal susceptibility index (FSI) [20]. As Cryptococcus neoformans and Candida krusei were susceptible to all the plant extracts, they exhibited the highest FSI value (100\%). This was followed by Candida albicans and Candida parapsilosis with FSI values of $97.2 \%$ and $94.4 \%$, respectively. The dermatophyte, Trichophyton interdigitale was sensitive to 26 of 36 extracts. Aspergillus fumigatus was considered as the most resistant fungus with a FSI value of $22 \%$. It was susceptible to only eight extracts belonging to three plants, which were Ailanthus triphysa (Dennst.) Alston (ethyl acetate, ethanol, methanol and water extracts), Asystasia gangetica (L.) T. Anderson (hexane, chloroform and ethyl acetate extracts) and Clinacanthus nutans (Burm. f.) Lindau (hexane extract). The MIC range recorded for these eight active extracts was $0.63-2.50 \mathrm{mg} / \mathrm{mL}$. None of these extracts could kill this filamentous fungus. On the other hand, these eight extracts appeared to have broad spectrum antifungal activity as they showed inhibitory activity against all the fungi used in this study.

Antibacterial assay

Chloramphenicol, which is an inhibitor of bacterial protein synthesis, was used as the positive control, and the MIC ranges recorded for the Gram-positive and Gram-negative bacteria in the assay were 2 - 16 and 2 - $64 \mu \mathrm{g} / \mathrm{mL}$, respectively. The plant extracts displayed lesser and weaker antibacterial activity compared to antifungal activity. As shown in Table II, bacteriostatic activity was recorded in $67.1 \%(145 / 216)$ of the bioassays whereas only $31.0 \%(67 / 216)$ of the bioassays exhibited bactericidal activity. The lowest MIC value was shown by the ethyl acetate extract of Gynostemma pentaphyllum (Thunb.) Makino against both Grampositive bacteria, Bacillus cereus and Staphylococcus aureus with a value of $0.08 \mathrm{mg} / \mathrm{mL}$. The lowest MBC value documented in this study was $0.31 \mathrm{mg} / \mathrm{mL}$, given by Asystasia gangetica (L.) T. Anderson (hexane extract against Klebsiella pneumoniae), Gynura bicolor (Roxb. ex Willd.) DC. (hexane and chloroform extracts against Escherichia coli and Klebsiella pneumoniae; ethyl acetate and ethanol extracts against Escherichia coli) and Turnera subulata Sm. (hexane extract against Escherichia coli).

Although Acinetobacter baumannii, Escherichia coli, Klebsiella pneumoniae and Pseudomonas aeruginosa are classified as Gram-negative bacteria, their susceptibilities to plant extracts were different (Table II). Based on MIC values, Pseudomonas aeruginosa was susceptible to all 36 plant extracts, followed by Klebsiella pneumoniae (27 extracts), Escherichia coli (20 extracts) and Acinetobacter baumannii (9 extracts). Acinetobacter baumannii was also shown the lowest bacterial susceptibility index (BSI) of $25 \%$ in the assay, being susceptible to the nine plant extracts with a MIC range of $0.63-2.50 \mathrm{mg} / \mathrm{mL}$. Among these nine extracts, only ethanol extracts of Gynura bicolor (Roxb. ex Willd.) DC. and Turnera subulata $\mathrm{Sm}$. showed bactericidal activity $(\mathrm{MBC}=2.50 \mathrm{mg} / \mathrm{mL})$. 
Table II

Minimum inhibitory concentration (MIC) and minimum bactericidal concentration (MBC) of extracts from six medicinal plants against Gram-positive and Gram-negative bacteria

\begin{tabular}{|c|c|c|c|c|c|c|c|c|c|c|c|c|}
\hline & \multicolumn{4}{|c|}{ Gram-positive bacteria } & \multicolumn{8}{|c|}{ Gram-negative bacteria } \\
\hline \multirow[t]{2}{*}{ Extract } & \multicolumn{2}{|c|}{ Bacillus cereus } & \multicolumn{2}{|c|}{$\begin{array}{c}\text { Staphylococcus } \\
\text { aureus }\end{array}$} & \multicolumn{2}{|c|}{$\begin{array}{c}\text { Acinetobacter } \\
\text { baumannii }\end{array}$} & \multicolumn{2}{|c|}{ Escherichia coli } & \multicolumn{2}{|c|}{$\begin{array}{c}\text { Klebsiella } \\
\text { pneumoniae }\end{array}$} & \multicolumn{2}{|c|}{$\begin{array}{c}\text { Pseudomonas } \\
\text { aeruginosa }\end{array}$} \\
\hline & MIC $^{\mathbf{a}}$ & MBC $^{\mathbf{a}}$ & MIC & MBC & MIC & MBC & MIC & MBC & MIC & MBC & MIC & MBC \\
\hline \multicolumn{13}{|c|}{ Ailanthus triphysa (Dennst.) Alston } \\
\hline HE & 1.25 & NA & 1.25 & 2.50 & NA & - & NA & - & 1.25 & NA & 0.63 & NA \\
\hline $\mathrm{CH}$ & 1.25 & NA & 2.50 & NA & NA & - & NA & - & 2.50 & NA & 0.63 & NA \\
\hline EA & 0.63 & NA & 0.63 & 1.25 & 1.25 & NA & 2.50 & NA & 0.63 & NA & 0.31 & NA \\
\hline ET & 1.25 & 1.25 & 1.25 & NA & 1.25 & NA & NA & - & 2.50 & 2.50 & 1.25 & 1.25 \\
\hline MT & 1.25 & 1.25 & 1.25 & 2.50 & NA & - & NA & - & 2.50 & NA & 1.25 & 1.25 \\
\hline WA & 2.50 & NA & 1.25 & NA & NA & - & NA & - & NA & - & 2.50 & NA \\
\hline \multicolumn{13}{|c|}{ Asystasia gangetica (L.) T. Anderson } \\
\hline $\mathrm{HE}$ & 0.63 & 0.63 & 0.31 & NA & NA & - & 0.31 & NA & 0.31 & 0.31 & 2.50 & 2.50 \\
\hline $\mathrm{CH}$ & 1.25 & 1.25 & 2.50 & NA & NA & - & 0.63 & NA & 1.25 & 1.25 & 0.63 & 1.25 \\
\hline EA & 0.63 & 0.63 & 1.25 & NA & NA & - & 0.63 & NA & 0.63 & 0.63 & 0.63 & 1.25 \\
\hline ET & 1.25 & 1.25 & 2.50 & NA & NA & - & 0.63 & NA & 1.25 & 1.25 & 0.63 & 1.25 \\
\hline MT & 1.25 & 1.25 & 1.25 & NA & NA & - & 0.63 & NA & 0.63 & 0.63 & 0.63 & 1.25 \\
\hline WA & NA & - & NA & - & NA & - & 2.50 & NA & $\mathrm{NA}$ & - & 1.25 & 1.25 \\
\hline \multicolumn{13}{|c|}{ Clinacanthus nutans (Burm. f.) Lindau } \\
\hline HE & 1.25 & 1.25 & 2.50 & NA & NA & - & 0.63 & NA & 1.25 & 1.25 & 1.25 & 2.50 \\
\hline $\mathrm{CH}$ & 2.50 & 2.50 & NA & - & NA & - & NA & - & NA & - & 0.63 & NA \\
\hline EA & 0.63 & 1.25 & 2.50 & NA & NA & - & 0.63 & NA & 0.63 & 0.63 & 0.63 & NA \\
\hline ET & 2.50 & 2.50 & NA & - & NA & - & NA & - & 2.50 & 2.50 & 0.63 & NA \\
\hline MT & NA & - & NA & - & NA & - & NA & - & NA & - & 0.63 & NA \\
\hline WA & NA & - & NA & - & NA & - & NA & - & NA & - & 2.50 & NA \\
\hline \multicolumn{13}{|c|}{ Gynostemma pentaphyllum (Thunb.) Makino } \\
\hline $\mathrm{HE}$ & 0.31 & NA & 0.63 & 2.50 & NA & - & NA & - & 0.63 & NA & 1.25 & NA \\
\hline $\mathrm{CH}$ & 0.16 & NA & 0.31 & 2.50 & 1.25 & NA & NA & - & 0.31 & NA & 0.63 & NA \\
\hline EA & 0.08 & NA & 0.08 & 2.50 & 0.63 & NA & NA & - & 0.16 & 2.50 & 0.63 & NA \\
\hline ET & 1.25 & NA & 1.25 & 2.50 & NA & - & NA & - & 1.25 & 2.50 & 0.63 & NA \\
\hline MT & NA & - & NA & - & NA & - & NA & - & NA & - & 0.63 & NA \\
\hline WA & NA & - & NA & - & NA & - & NA & - & NA & - & 1.25 & NA \\
\hline \multicolumn{13}{|c|}{ Gynura bicolor (Roxb. ex Willd.) DC. } \\
\hline $\mathrm{HE}$ & 0.31 & NA & 0.63 & 0.63 & NA & - & 0.31 & 0.31 & 0.31 & 0.31 & 2.50 & NA \\
\hline $\mathrm{CH}$ & 0.31 & NA & 0.63 & 1.25 & NA & - & 0.31 & 0.31 & 0.31 & 0.31 & 0.63 & NA \\
\hline EA & 0.63 & NA & 1.25 & 2.50 & 2.50 & NA & 0.31 & 0.31 & 0.63 & 0.63 & 0.63 & NA \\
\hline ET & 0.63 & NA & 1.25 & NA & 2.50 & 2.50 & 0.31 & 0.31 & 0.63 & 0.63 & 0.63 & NA \\
\hline MT & 1.25 & NA & 2.50 & NA & NA & - & 0.63 & 0.63 & 0.63 & 0.63 & 0.63 & NA \\
\hline WA & NA & - & NA & - & NA & - & 2.50 & 2.50 & NA & - & 1.25 & NA \\
\hline \multicolumn{13}{|c|}{ Turnera subulata $\mathrm{Sm}}$. \\
\hline HE & 0.63 & NA & 0.63 & 0.63 & NA & - & 0.31 & 0.31 & 0.63 & 0.63 & 1.25 & NA \\
\hline $\mathrm{CH}$ & 0.63 & NA & 1.25 & 1.25 & NA & - & 0.63 & 0.63 & 0.63 & 0.63 & 0.63 & NA \\
\hline EA & 0.63 & NA & 1.25 & 2.50 & 2.50 & NA & 0.63 & 0.63 & 0.63 & 0.63 & 0.63 & NA \\
\hline ET & NA & - & NA & - & 1.25 & 2.50 & 2.50 & 2.50 & 2.50 & 2.50 & 0.63 & NA \\
\hline MT & 2.50 & NA & NA & - & 1.25 & NA & 2.50 & 2.50 & 2.50 & 2.50 & 0.63 & NA \\
\hline WA & NA & - & NA & - & NA & - & NA & - & NA & - & 1.25 & NA \\
\hline Antibiotic $^{\mathrm{b}}$ & $2-4$ & & $8-16$ & & 64 & & $4-8$ & & $2-4$ & & $32-64$ & \\
\hline
\end{tabular}

a The MIC and MBC values are expressed as the mean of three consistent replicates in $\mathrm{mg} / \mathrm{mL}$. ${ }^{\mathrm{b}}$ Chloramphenicol was used as the positive control and the values are expressed in $\mu \mathrm{g} / \mathrm{mL}$. HE, hexane extract; $\mathrm{CH}$, chloroform extract; EA, ethyl acetate extract; ET, ethanol extract; MT, methanol extract; WA, water extract; NA denotes no activity while "_" denotes not tested due to absence of inhibitory activity.

\section{Cytotoxicity assay}

The viability of Vero cells treated with plant extracts was ascertained by the neutral red uptake assay and the calculated percentages of viability are illustrated in Figure 1. Different plants and different extracts of a plant exhibited different degrees of toxicities on the mammalian cells. Extracts from Asystasia gangetica (L.) T. Anderson (hexane, chloroform and water; $\mathrm{p}>0.10$ ),
Clinacanthus nutans (Burm. f.) Lindau (methanol and water; p > 0.06), Gynostemma pentaphyllum (Thunb.) Makino (water; $\mathrm{p}=0.85$ ) and Turnera subulata $\mathrm{Sm}$. (ethanol, methanol and water; $\mathrm{p}>0.20$ ) did not cause significant toxicity to the Vero cells, even at the highest concentration tested, i.e. $640 \mu \mathrm{g} / \mathrm{mL}$. The extracts of Ailanthus triphysa (Dennst.) Alston and Gynura bicolor (Roxb. ex Willd.) DC. were 
FARMACIA, 2020, Vol. 68, 4

relatively more toxic to the mammalian cells than the other four medicinal plants as all the extracts of both plants were significantly cytotoxic $(\mathrm{p}<0.05)$ to the cells. The ethyl acetate extract of Gynura bicolor (Roxb. ex Willd.) DC. showed cytotoxicity at concentration starting from $20 \mu \mathrm{g} / \mathrm{mL}$ whereas the chloroform and ethyl acetate extracts of Ailanthus triphysa (Dennst.) Alston demonstrated cytotoxicity at concentrations starting from 5 and $20 \mu \mathrm{g} / \mathrm{mL}$, respectively. The chloroform extract of Ailanthus triphysa (Dennst.) Alston was the most cytotoxic of all tested extracts as the cell viability recorded at the lowest concentration used, i.e. $5 \mu \mathrm{g} / \mathrm{mL}$ was $67.7 \% \pm 2.30 \%$. The extent of toxicity of this extract was also reflected by its median cytotoxic concentration value, $9.7 \pm 0.4 \mu \mathrm{g} / \mathrm{mL}$, which was the lowest among all the extracts in the study (Table III).

Table III

Median cytotoxic concentrations $\left(\mathrm{CC}_{50}\right)$ of various extracts obtained from six medicinal plants on African monkey kidney epithelial (Vero) cells

\begin{tabular}{|l|c|c|c|c|c|c|}
\hline \multirow{2}{*}{ Plant extracts } & \multicolumn{6}{|c|}{ Median cytotoxic concentration ( $\mu$ g/mL) } \\
\cline { 2 - 7 } & $\begin{array}{c}\text { Ailanthus } \\
\text { triphysa } \\
\text { (Dennst.) Alston }\end{array}$ & $\begin{array}{c}\text { Asystasia } \\
\text { gangetica }(\mathrm{L} .) \\
\text { T. Anderson }\end{array}$ & $\begin{array}{c}\text { Clinacanthus } \\
\text { nutans (Burm. f.) } \\
\text { Lindau }\end{array}$ & $\begin{array}{c}\text { Gynostemma } \\
\text { pentaphyllum } \\
\text { (Thunb.) Makino }\end{array}$ & $\begin{array}{c}\text { Gynura } \\
\text { bicolor (Roxb. } \\
\text { ex Willd.) DC. }\end{array}$ & $\begin{array}{c}\text { Turnera } \\
\text { subulata } \\
\text { Sm. }\end{array}$ \\
\hline Hexane & $120.4 \pm 11.7$ & - & $560.7 \pm 21.8$ & $588.4 \pm 29.2$ & $>640$ & $471.3 \pm 8.9$ \\
\hline Chloroform & $9.7 \pm 0.4$ & - & $593.4 \pm 24.3$ & $88.1 \pm 14.5$ & $121.1 \pm 8.9$ & $281.4 \pm 16.7$ \\
\hline Ethyl acetate & $30.5 \pm 4.3$ & $486.5 \pm 19.0$ & $141.8 \pm 13.3$ & $126.2 \pm 7.2$ & $32.7 \pm 3.8$ & $245.4 \pm 5.6$ \\
\hline Ethanol & $133.0 \pm 4.4$ & $141.3 \pm 10.1$ & $>640$ & $243.8 \pm 10.0$ & $58.0 \pm 2.9$ & - \\
\hline Methanol & $142.8 \pm 10.8$ & $220.6 \pm 22.6$ & - & $605.0 \pm 54.0$ & $56.7 \pm 3.0$ & - \\
\hline Water & $>640$ & - & - & - & $>640$ & - \\
\hline
\end{tabular}

“-” denotes could not be determined as no significant toxicity was observed at the highest concentration $(640 \mu \mathrm{g} / \mathrm{mL})$.
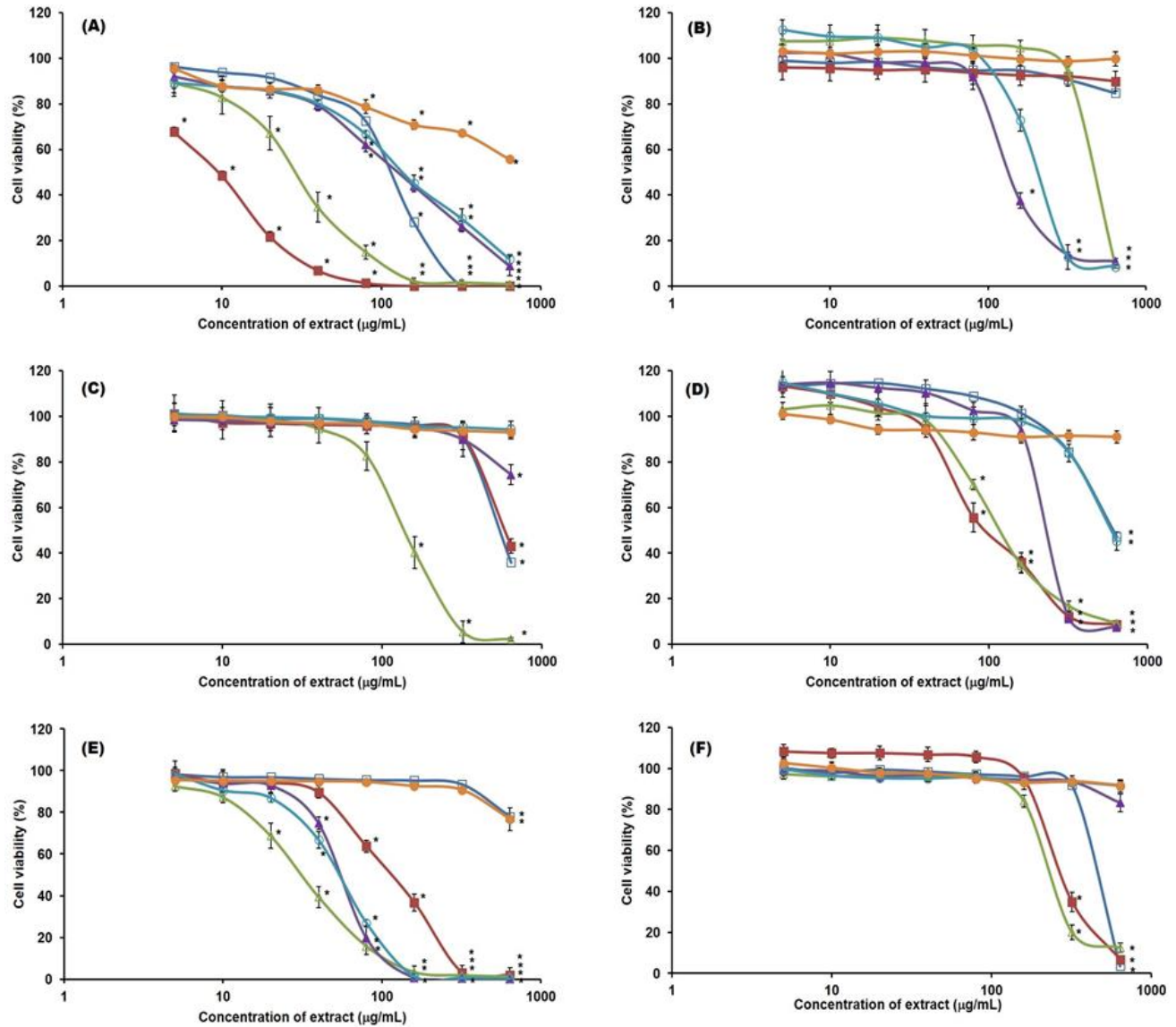

Figure 1.

Viability of African monkey kidney epithelial (Vero) cells treated with various extracts of six medicinal plants.

The cell viability was assessed using the neutral red uptake assay

The results represent mean $\pm S D, n=3$. The asterisk mark indicates significant difference $(p<0.05)$ when analysed with oneway ANOVA test. (A) - Ailanthus triphysa (Dennst.) Alston; (B) - Asystasia gangetica (L.) T. Anderson; (C) - Clinacanthus nutans (Burm. f.) Lindau; (D) - Gynostemma pentaphyllum (Thunb.) Makino; (E) - Gynura bicolor (Roxb. ex Willd.) DC.;

(F) - Turnera subulata Sm. $(\square)$ - hexane extract; $(\boldsymbol{\square})$ - chloroform extract; $(\triangle)$ - ethyl acetate extract; $(\boldsymbol{\Delta})$ - ethanol extract; $(\bigcirc)$ - methanol extract; $(\bigcirc)$ - water extract 
FARMACIA, 2020, Vol. 68, 4

The solvents used for sequential extraction can be classified as non-polar (hexane and chloroform), intermediate polar (ethyl acetate) and polar (ethanol, methanol and water extracts). Within the extract concentration range $(0.02-2.50 \mathrm{mg} / \mathrm{mL})$ examined in this study, broad spectrum antifungal activity was noted in the extracts derived from non-polar (hexane and chloroform extracts of Asystasia gangetica (L.) T. Anderson, and hexane extract of Clinacanthus nutans (Burm. f.) Lindau), intermediate polar (ethyl acetate extracts of Ailanthus triphysa (Dennst.) Alston and Asystasia gangetica (L.) T. Anderson) and polar (ethanol, methanol and water extracts of Ailanthus triphysa (Dennst.) Alston) solvents. However, in the antibacterial assay, broad spectrum activity was only observed in extracts obtained using intermediate polarity (ethyl acetate extracts of Ailanthus triphysa (Dennst.) Alston, Gynura bicolor (Roxb. ex Willd.) DC. and Turnera subulata $\mathrm{Sm}$.) and polar (ethanol extract of Gynura bicolor (Roxb. ex Willd.) DC.) solvents. This might be due to differences in the morphology between bacteria (a prokaryote) and fungi (a eukaryote), and phytochemicals solubilised in solvents of different polarity during extraction $[4,12]$. However, it is not known whether a single compound or a mixture of several compounds contributed to the broad spectrum activity. It is noted that the ethyl acetate extract of Ailanthus triphysa (Dennst.) Alston was active against all the bacteria and fungi evaluated for this study. This suggests that ethyl acetate is a suitable solvent for extracting antimicrobial compounds from plants. Phytochemicals that have been commonly reported being extracted by ethyl acetate solvent include alkaloids, cardiac glycosides, flavonoids, terpenoids, phenolics, saponins and steroids [15, 19, 33]. To our knowledge, the antibacterial and antifungal activities are reported for the first time from Ailanthus triphysa (Dennst.) Alston.

A plant extract is a mixture of bioactive and nonbioactive phytochemicals, thus the potency of the extract is usually lower than that of pure antibiotics such as amphotericin B and chloramphenicol, as reflected by the MIC values for the antibiotics and the plant extracts in this study (Tables I and II). Standardised criteria for classification of plant extracts with antimicrobial activity are at present unavailable. Saraiva et al. [32] proposed that, a plant extract with antimicrobial activity can be categorised as highly active (MIC $\leq 0.1 \mathrm{mg} / \mathrm{mL})$, active $(0.1 \mathrm{mg} / \mathrm{mL}<\mathrm{MIC} \leq 0.5$ $\mathrm{mg} / \mathrm{mL})$, moderately active $(0.5 \mathrm{mg} / \mathrm{mL}<\mathrm{MIC} \leq 1$ $\mathrm{mg} / \mathrm{mL})$, weakly active $(1 \mathrm{mg} / \mathrm{mL}<\mathrm{MIC} \leq 2 \mathrm{mg} / \mathrm{mL})$ and inactive (MIC $>2 \mathrm{mg} / \mathrm{mL}$ ). By adopting this proposed classification for antibacterial assays, only the ethyl acetate extract of Gynostemma pentaphyllum (Thunb.) Makino may be regarded as highly active against both Gram-positive bacteria, Bacillus cereus and Staphylococcus aureus (Table II). In contrast, all the six extracts of Gynura bicolor (Roxb. ex Willd.)
DC. and five of the six extracts of Asystasia gangetica (L.) T. Anderson were considered highly active against the yeast Cryptococcus neoformans (Table I). Four extracts (ethyl acetate, ethanol, methanol and water) from Ailanthus triphysa (Dennst.) Alston were regarded as highly active against the three Candida species. The ethyl acetate extract of Ailanthus triphysa (Dennst.) Alston was regarded as the only highly active extract against the dermatophyte, Trichophyton interdigitale. The antifungal and antibacterial results obtained for Asystasia gangetica (L.) T. Anderson (fresh aerial part) in this study were in coherent with the study by Hamid et al. [16] but with much lower MIC ranges, $0.02-2.50$ and $0.31-2.50 \mathrm{mg} / \mathrm{mL}$, respectively. The susceptible concentration ranges reported by Hamid et al. [16] using dried whole plant extracts against fungi and bacteria were 6.25 - 200 and $25-200 \mathrm{mg}$ / $\mathrm{mL}$, respectively. It has been reported that fresh and dried materials of the same plant may have different phytochemical contents and antimicrobial potency [1, 24].

It is evident that the extracts of Clinacanthus nutans (Burm. f.) Lindau possess antimicrobial property against all the fungi and bacteria (except Acinetobacter baumannii). Clinacanthus nutans (Burm. f.) Lindau has also been shown to inhibit the growth of two acne-inducing bacteria, Propionibacterium acnes and Staphylococcus epidermidis [6]. While the cytotoxicity for methanol extract of Clinacanthus nutans (Burm. f.) Lindau on Vero cells was comparable to that one reported by Kunsorn et al. [22], the $\mathrm{CC}_{50}$ value for hexane extract $(560.7 \mu \mathrm{g} / \mathrm{mL})$ obtained was much lower compared to that of Kunsorn et al. [22] study (> $1600 \mu \mathrm{g} / \mathrm{mL}$ ). This difference could be attributed to the type of sample used (fresh vs. dried leaves) or geographical region (Malaysia vs. Thailand). Different cell viability assay used (neutral red uptake assay vs. MTT assay) may also influence the $\mathrm{CC}_{50}$ values [5].

The dried leaf extracts of Turnera subulata Sm. were qualitatively found to be active against bacteria Klebsiella pneumoniae, Proteus vulgaris and Staphylococcus aureus using the disc diffusion method [25], and against fungi Candida albicans, Candida glabrata, Aspergillus spp. and Penicillium chrysogenum using the well diffusion method [28]. The results indicate that extracts of Turnera subulata $\mathrm{Sm}$. possess broad spectrum antimicrobial activity.

The antifungal assay revealed that Aspergillus fumigatus was the most resistant fungus with a FSI value of $22 \%$. Such resistivity towards plant extracts has been noted by other researchers for Aspergillus fumigatus [26, 29, 40], Aspergillus flavus [26, 40], Aspergillus niger [23, 26, 29], Aspergillus brasiliensis [20] and Aspergillus nidulans [29]. The resistivity of Aspergillus spp. to plant extracts has underlined the importance of bioprospecting for natural resources. 


\section{Conclusions}

The results showed that the antifungal and antibacterial properties of a plant extract depend on the plant species, type of solvent used for extraction, microbial species being tested and the extract concentration was used in the bioassay. The cytotoxicity of a plant extract also depends on the plant species, type of extractant and extract concentration used. The results indicated that the hexane and chloroform extracts of Asystasia gangetica (L.) T. Anderson are non-toxic to Vero cells, potent and have broad spectrum activity against human fungal pathogens. The two extracts are potential sources of new antifungal compounds and will be subjected to isolation and characterisation of active compounds.

\section{Acknowledgement}

The authors thank Universiti Tunku Abdul Rahman for the financial support given to the project and the Research Scholarship Scheme granted to Cheong Wei Ong (IPSR/RMC/UTARRF/2012-C2/S03) and Yik Sin Chan (IPSR/RMC/UTARRF/2012-C2/K03) for their Master of Science candidature.

\section{Conflict of interest}

The authors declare no conflict of interest.

\section{References}

1. Alabi OA, Haruna MT, Anokwuru CP, Jegede T, Abia H, Okegbe VU, Esan BE, Comparative studies on antimicrobial properties of extracts of fresh and dried leaves of Carica papaya (L) on clinical bacterial and fungal isolates. Adv Appl Sci Res., 2012; 3(5): 3107-3114

2. Arendrup MC, Update on antifungal resistance in Aspergillus and Candida. Clin Microbiol Infect., 2014; 20(Suppl. 6): 42-48.

3. Arullappan S, Rajamanickam P, Thevar N, Kodimani $\mathrm{CC}$, In vitro screening of cytotoxic, antimicrobial and antioxidant activities of Clinacanthus nutans (Acanthaceae) leaf extracts. Trop J Pharm Res., 2014; 13(9): 1455-1461.

4. Brooks GF, Carroll KC, Butel JS, Morse SA, Mietzner TA, Jawetz, Melnick, \& Adelberg's medical microbiology. $26^{\text {th }}$ ed. China: McGraw-Hill Education; 2012.

5. Chan SM, Khoo KS, Sit NW, Interactions between plant extracts and cell viability indicators during cytotoxicity testing. Implications for ethnopharmacological studies. Trop J Pharm Res., 2015; 14(11): 1991-1998.

6. Chomnawang MT, Surassmo S, Nukoolkarn VS, Gritsanapan W, Antimicrobial effects of Thai medicinal plants against acne-inducing bacteria. J Ethnopharmacol., 2005; 101(1-3): 330-333.

7. Ciorba V, Odone A, Veronesi L, Pasquarella C, Signorelli C, Antibiotic resistance as a major public health concern: Epidemiology and economic impact. Ann Ig., 2015; 27(3): 562-579.

8. Clinical and Laboratory Standards Institute, Performance standards for antimicrobial susceptibility testing; fifteenth informational supplement, CLSI Document M100-S15. Pennsylvania: Clinical and Laboratory Standards Institute; 2005.

9. Clinical and Laboratory Standards Institute, Reference method for broth dilution antifungal susceptibility testing of yeasts; approved standard-second edition, CLSI Document M27-A2. Pennsylvania: Clinical and Laboratory Standards Institute; 2002.

10. Clinical and Laboratory Standards Institute, Reference method for broth dilution antifungal susceptibility testing of filamentous fungi; approved standard, CLSI Document M38-A. Pennsylvania: Clinical and Laboratory Standards Institute; 2002.

11. Cos P, Vlietinck AJ, Berghe DV, Maes L, Antiinfective potential of natural products: How to develop a stronger in vitro 'proof-of-concept'?. J Ethnopharmacol., 2006; 106(3): 290-302.

12. Cowan MM, Plant products as antimicrobial agents. Clin Microbiol Rev., 1999; 12(4): 564-582.

13. Denning DW, Hope WW, Therapy for fungal diseases: Opportunities and priorities. Trends Microbiol., 2010; 18(5): 195-204.

14. Eloff JN, A sensitive and quick microplate method to determine the minimal inhibitory concentration of plant extracts for bacteria. Planta Med., 1998; 64(8): 711-713.

15. Godwill EA, Paul N, Chidubem NJ, Innocent OT, Chinenye EB, Comparative qualitative analysis of the phytochemical load of water, methanol, ethyl acetate and hexane extracts of six selected medicinal plants. Int J Pharmacogn Phytochem Res., 2013; 5(3): 164-167.

16. Hamid AA, Aiyelaagbe OO, Ahmed RN, Usman LA, Adebayo SA, Preliminary phytochemistry, antibacterial and antifungal properties of extracts of Asystasia gangetica Linn T. Anderson grown in Nigeria. $A d v$ Appl Sci Res., 2011; 2(3): 219-226.

17. Havlickova B, Czaika VA, Friedrich M, Epidemiological trends in skin mycoses worldwide. Mycoses, 2008; 51(Suppl. 4): 2-15.

18. Katzung B, Trevor A, Basic and clinical pharmacology. $13^{\text {th }}$ ed. USA: McGraw-Hill Education; 2015.

19. Khanam Z, Chew SW, Bhat IUH, Phytochemical screening and antimicrobial activity of root and stem extracts of wild Eurycoma longifolia Jack (Tongkat Ali). J King Saud Univ Sci., 2015; 27(1): 23-30.

20. Khoo KS, Gwee PS, Beh V, Chung TC, Tan LY, Sit NW, Ong HC, Antifungal and antibacterial properties of three medicinal plants from Malaysia. Acta Hortic., 2014; 1023: 109-116.

21. Kriengkauykiat J, Ito JI, Dadwal SS, Epidemiology and treatment approaches in management of invasive fungal infections. Clin Epidemiol., 2011; 3: 175-191.

22. Kunsorn P, Ruangrungsi N, Lipipun V, Khanboon A, Rungsihirunrat K, Chaijaroenkul W, The identities and anti-herpes simplex virus activity of Clinacanthus nutans and Clinacanthus siamensis. Asian Pac J Trop Biomed., 2013; 3(4): 284-290.

23. Maregesi SM, Pieters L, Ngassapa OD, Apers S, Vingerhoets R, Cos P, Berghe DA, Screening of some Tanzanian medicinal plants from Bunda district for antibacterial, antifungal and antiviral activities. $J$ Ethnopharmacol., 2008; 119(1): 58-66. 
24. Mondal S, Mahapatra SC, Mirdha BR, Naik SN, Antimicrobial activities of essential oils obtained from fresh and dried leaves of Ocimum sanctum (L.) against enteric bacteria and yeast. Acta Hortic., 2007; 756: 267-270.

25. Murugan T, Rajendran P, Screening for antibacterial activity of Turnera subulata extracts against human pathogens. Int J Pharm Biol Arch., 2011; 2(5): 1456-1459.

26. Muschietti L, Derita M, Sülsen V, de Dios Muñoz J, Ferraro G, Zacchino S, Martino V, In vitro antifungal assay of traditional Argentine medicinal plants. $J$ Ethnopharmacol., 2005; 102(2): 233-238.

27. Nenoff P, Krüger C, Ginter-Hanselmayer G, Tietz HJ, Mycology - an update. Part 1: Dermatomycoses: Causative agents, epidemiology and pathogenesis. $J$ Dtsch Dermatol Ges., 2014; 12(3): 188-209.

28. Prabhahar C, Saleshrani K, Saranraj P, Tharmaraj K, Studies on the antifungal activity of Turnera subulata and Acacia nilotica against selected fungal pathogens. Int J Recent Sci Res., 2012; 3(3): 149-154.

29. Rangkadilok N, Tongchusak S, Boonhok R, Chaiyaroj SC, Junyaprasert VB, Buajeeb W, Akanimanee J, Raksasuk T, Suddhasthira T, Satayavivad J, In vitro antifungal activities of longan (Dimocarpus longan Lour.) seed extract. Fitoterapia, 2012; 83(3): 545-553.

30. Repetto G, del Peso A, Zurita JL, Neutral red uptake assay for the estimation of cell viability/cytotoxicity. Nat Protoc., 2008; 3(7): 1125-1131.

31. Samer M, Neal MD, Basil DR, Anti-hyperlipidemic and hypoglycemic effects of Gynostemma pentaphyllum in the Zucker fatty rat. J Pharm Pharm Sci., 2006; 9(3): 281-291.

32. Saraiva AM, Castro RHA, Cordeiro RP, Sobrinho TJSP, Castro VTNA, Amorim ELC, Xavier HS, Pisciottano MNC, In vitro evaluation of antioxidant, antimicrobial and toxicity properties of extracts of Schinopsis brasiliensis Engl. (Anacardiaceae). Afr J Pharm Pharmacol., 2011; 5(14): 1724-1731.

33. Sheikh N, Kumar Y, Misra AK, Pfoze L, Phytochemical screening to validate the ethnobotanical importance of root tubers of Dioscorea species of Meghalaya, North East India. J Med Plants Stud., 2013; 1(6): 62-69.

34. Siew YY, Zareisedehizadeh S, Seetoh WG, Neo SY, Tan CH, Koh HL, Ethnobotanical survey of usage of fresh medicinal plants in Singapore. J Ethnopharmacol., 2014; 155(3): 1450-1466.

35. Sipahi OR, Economics of antibiotic resistance. Exp Rev Anti Infect Ther., 2008; 6(4): 523-539.

36. Soares LA, de Cássia Orlandi Sardi J, Gullo FP, de Souza Pitangui N, Scorzoni L, Leite FS, Giannini MJ, Almeida AM, Anti dermatophytic therapy -prospects for the discovery of new drugs from natural products. Braz J Microbiol., 2013; 44(4): 1035-1041.

37. Teoh WY, Sim KS, Moses Richardson JS, Wahab NA, Hoe SZ, Antioxidant capacity, cytotoxicity, and acute oral toxicity of Gynura bicolor. Evid Based Complem Alternat Med., 2013; 2013: 958407: 1-10.

38. Tilloo SK, Pande VB, Rasala TM, Kale VV, Asystasia gangetica: Review on multipotential application. Int Res J Pharm., 2012; 3(4): 18-20.

39. Tu SF, Liu RH, Cheng YB, Hsu YM, Du YC, ElShazly M, Wu YC, Chang FR, Chemical constituents and bioactivities of Clinacanthus nutans aerial parts. Molecules, 2014; 19(12): 20382-20390.

40. Webster D, Taschereau P, Belland RJ, Sand C, Rennie RP, Antifungal activity of medicinal plant extracts; preliminary screening studies. J Ethnopharmacol., 2008; 115(1): 140-146.

41. World Health Organization, Global health observatory data repository. 2016. http://www.who.int/gho/en/.

42. World Health Organization, Guidelines on conservation of medicinal plants. Geneva: International Union for the Conservation of Nature; 1993.

43. Wu CC, Lii CK, Liu KL, Chen PY, Antiinflammatory activity of Gynura bicolor (Hong Feng Cai) ether extract through inhibits nuclear factor kappa B activation. J Tradit Complem Med., 2013; 3(1): 48-52. 